\title{
Effect of time of maize silage supplementation on herbage intake, milk production, and nitrogen excretion of grazing dairy cows
}

\author{
O. Al-Marashdeh, ${ }^{* 1}$ P. Gregorini, $\dagger$ and G. R. Edwards* \\ *Department of Agricultural Sciences, Lincoln University, Lincoln, New Zealand 7647 \\ †DairyNZ, Cnr Ruakura and Morrinsville Roads, Newstead, Private Bag 3221, Hamilton 3240, New Zealand
}

\begin{abstract}
The objective of this study was to evaluate the effect of feeding maize silage at different times before a short grazing bout on dry matter (DM) intake, milk production, and $\mathrm{N}$ excretion of dairy cows. Thirty-six Friesian $\times$ Jersey crossbred lactating dairy cows were blocked in 9 groups of 4 cows by milk solids (sum of protein and fat) production $(1.26 \pm 0.25 \mathrm{~kg} / \mathrm{d})$, body weight (466 $\pm 65 \mathrm{~kg}$ ), body condition score $(4 \pm 0.48)$, and days in milk $(197 \pm 15)$. Groups were then randomly assigned to 1 of 3 replicates of 3 treatments: control; herbage only, supplemented with $3 \mathrm{~kg}$ of $\mathrm{DM} /$ cow of maize silage after morning milking approximately $9 \mathrm{~h}$ before pasture allocation $(9 \mathrm{BH})$; and supplemented with $3 \mathrm{~kg}$ of $\mathrm{DM} /$ cow of maize silage before afternoon milking approximately $2 \mathrm{~h}$ before pasture allocation (2BH). Herbage allowance (above the ground level) was $22 \mathrm{~kg}$ of DM/cow per day for all groups of cows. Cows were allocated to pasture from 1530 to $2030 \mathrm{~h}$. Maize silage DM intake did not differ between treatments, averaging $3 \mathrm{~kg}$ of DM/cow per day. Herbage DM intake was greater for control than $2 \mathrm{BH}$ and $9 \mathrm{BH}$, and greater for $9 \mathrm{BH}$ than $2 \mathrm{BH}(11.1,10.1$, and $10.9 \mathrm{~kg}$ of $\mathrm{DM} /$ cow per day for control, $2 \mathrm{BH}$, and 9BH, respectively). The substitution rate (kilograms of herbage DM per kilograms of maize silage $\mathrm{DM}$ ) was greater for $2 \mathrm{BH}(0.47)$ than 9BH (0.19). Milk solids production was similar between treatments (overall mean $1.2 \mathrm{~kg} /$ cow per day). Body weight loss tended to be less for supplemented than control cows $(-0.95,-0.44$, and $-0.58 \mathrm{~kg} /$ cow per day for control, 2BH, and 9BH, respectively). Nitrogen concentration in urine was not affected by supplementation or time of supplementation, but estimated urinary $\mathrm{N}$ excretion tended to be greater for control than supplemented cows when urinary $\mathrm{N}$ excretion estimated using plasma or milk urea N. At the time of herbage meal, nonesterified fatty acid concentration was greater for
\end{abstract}

Received November 24, 2015.

Accepted May 31, 2016.

${ }^{1}$ Corresponding author: omar.al-marashdeh@lincoln.ac.nz control than supplemented cows and greater for $9 \mathrm{BH}$ than $2 \mathrm{BH}(0.58,0.14$, and $0.26 \mathrm{mmol} / \mathrm{L}$ for control, $2 \mathrm{BH}$, and $9 \mathrm{BH}$, respectively). Timing of maize silage supplementation relative to a short and intensive herbage meal can reduce the substitution rate and increase herbage DM intake of grazing dairy cows.

Key words: dairy cow, maize silage, nitrogen excretion, time of supplementation

\section{INTRODUCTION}

Herbage provides most of the nutrients requirements for grazing cows at a relatively low cost and, therefore, is the dietary base of New Zealand pastoral dairy production systems. However, seasonal variations in herbage growth rate and chemical composition, often limit herbage availability and energy intake, which compromises animal milk production (Valentine and Kemp, 2007). Nitrogen fertilizer is generally used to increase herbage production and fill seasonal deficits of herbage availability. Nitrogen fertilization, however, increases the $\mathrm{N}$ content of the plant and exacerbates the known N-to-fermentable carbohydrate imbalance of fresh temperate herbage. Excess of dietary $\mathrm{N}$ increases dairy cattle inefficiency of $\mathrm{N}$ utilization (Castillo et al., 2001), leading to high $\mathrm{N}$ loss to the environment (De Klein et al., 2010) through urinary $\mathrm{N}$ excretion (Pacheco and Waghorn, 2008). It has been suggested that restricting time at pasture could be a way to reduce urinary $\mathrm{N}$ deposition onto the pasture (Oudshoorn et al., 2008; Clark et al., 2010; Gregorini et al., 2010b). However, acute restrictions of available grazing time (e.g., 4-5 h) constrain herbage intake, limiting milk production of dairy cows (Pérez-Ramírez et al., 2008; Gregorini, 2012). Supplementation is a complementary feeding strategy to restrictions of time at pasture that can be used to increase feed intake and maintain milk production (Soca et al., 2014).

Time of supplementation relative to fresh pasture allocation has been reported to affect substitution of herbage by supplement (Hess et al., 2002; Gekara et al., 2005; Al-Marashdeh et al., 2015a,b) and milk produc- 
tion (Sheahan et al., 2013; Al-Marashdeh et al., 2015b). In an indoor feeding study, Al-Marashdeh et al. (2015b) reported $0.8 \mathrm{~kg}$ greater herbage DMI and $3.4 \mathrm{~kg}$ greater milk production by feeding maize silage to dairy cows at $9 \mathrm{~h}$ rather than $1 \mathrm{~h}$ before an intensive herbage meal. Time of supplementation has also been reported to affect the efficiency at which ruminal microbes convert ruminal ammonia $\mathrm{N}\left(\mathrm{NH}_{3}-\mathrm{N}\right)$ to microbial $\mathrm{N}$ (Mitani et al., 2005; Gregorini et al., 2010b; Al-Marashdeh et al., 2015b) and N partitioning of dairy cows (Mitani et al., 2005; Al-Marashdeh et al., 2015a). In a continuous culture fermentation study, Gregorini et al. (2010a) reported that feeding maize silage $9 \mathrm{~h}$ rather than $1 \mathrm{~h}$ before a single meal of herbage reduced ammonia $\mathrm{N}$ losses by $30 \%$ and increased glucogenic nutrient supply by 13\%. Both Gregorini et al. (2010a) and Al-Marashdeh et al. (2015a) concluded that, under pasture-restriction regimens, time of maize silage supplementation relative to the herbage meal is a feeding alternative to help manage and reduce urinary $\mathrm{N}$ excretion. Although the available evidence suggests positive effects of time of supplementation relative to pasture allocation on herbage intake, milk production, and $\mathrm{N}$ excretion, information is lacking on these potential benefits under grazing environments in which time at pasture (i.e., available grazing time) is restricted.

We hypothesized that herbage intake, milk production, and urinary $\mathrm{N}$ excretion would increase as a result of feeding maize silage 9 rather than $2 \mathrm{~h}$ before a short and intensive meal of grazed herbage. The objective of the current study was to investigate the effect of feeding maize silage 9 or $2 \mathrm{~h}$ before grazing on herbage DMI, milk production, and $\mathrm{N}$ excretion of late-lactation dairy cows.

\section{MATERIALS AND METHODS}

All procedures were approved by the Lincoln University Animal Ethics Committee (AEC 510).

\section{Experimental Site and Design}

The experiment was conducted at the Lincoln University Research Dairy Farm, Lincoln, New Zealand $\left(43^{\circ} 38^{\prime} \mathrm{S}, 172^{\circ} 27^{\prime} \mathrm{E}\right)$, from March 6 to 26,2013 , on perennial ryegrass dominated sward (Lolium perenne L., $84.9 \%$; Trifolium repens, $4.5 \%$; weed, $4.7 \%$; and dead material, $5.8 \%$ ) grazed by dairy cows in late-lactation. Thirty-six Friesian $\times$ Jersey crossbred, lactating dairy cows were blocked into 9 groups of 4 cows by milk solids production $(1.26 \pm 0.25 \mathrm{~kg} / \mathrm{d}$; mean $\pm \mathrm{SD})$, BW $(466 \pm 65 \mathrm{~kg})$, BCS $(4 \pm 0.48$; scale $1-10)$, and DIM $(197 \pm 15)$. Groups were then randomly assigned to 1 of 3 replicates of 3 treatments: control; herbage only, supplemented with $3 \mathrm{~kg}$ of DM of maize silage after morning milking approximately $9 \mathrm{~h}$ before pasture allocation $(\mathbf{9 B H})$; and supplemented with $3 \mathrm{~kg}$ of DM of maize silage before afternoon milking approximately $2 \mathrm{~h}$ before pasture allocation $(\mathbf{2 B H})$, as presented in Figure 1. Herbage allowance (above ground level) was $22 \mathrm{~kg}$ of DM/cow per day from 1530 to $2030 \mathrm{~h}$ (grazing session). Herbage allowance and the estimated herbage mass per unit of area determined the area allocated (per cow) to graze daily. Herbage mass was determined using an electronic rising plate meter (RPM; Jenquip F150 Electronic Pasture Meter, Fielding, New Zealand). The compressed sward surface height of the area immediately in front of each group of cows was recorded from 30 random plate meter readings, and herbage DM mass estimated using the plate meter's internal calibration $(\mathrm{RPM} \times 140+500 \mathrm{~kg}$ of DM/ha $)$.

Cows were milked twice daily (0600 and $1430 \mathrm{~h}$ ), and maintained on a stand-off area (a harrowed paddock with no access to herbage) with ad libitum access to the fresh water. The experiment was conducted over a period of $21 \mathrm{~d}$, with $12 \mathrm{~d}$ of adaptation to the treatment and $9 \mathrm{~d}$ of measurements. During the adaptation period, maize silage was gradually increased in the diet (1 $\mathrm{kg}$ of DM every second day) until $3 \mathrm{~kg}$ of DM of maize silage was reached. Maize silage was fed to the cows indoors in individual bins.

\section{Sward and Feeding Regimen}

Four 1.5-ha paddocks were used for the experiment. Half of each paddock (0.75 ha) was grazed to $5 \mathrm{~cm}$ above ground level and fertilized with $50 \mathrm{~kg}$ of N/ha as urea $4 \mathrm{wk}$ before the experiment started. Three weeks before the start of the experiment, the second half of each paddock was grazed and fertilized. During the experiment, cows strip-grazed the first half of each paddock (4 wk of regrowth) before strip-grazing the second half. This procedure ensured that sward's plants were at similar phenological stage and herbage had similar feeding value throughout experiment.

\section{Measurements and Analysis}

Herbage DMI. The herbage DMI was estimated per group by difference between pre- and postgrazing herbage mass. Herbage mass was estimated, through compressed sward surface height, using an RPM (Kellaway et al., 1993). A total of 30 RPM measurements were taken pre- and postgrazing in each group grazing area. To calibrate height measurements of the sward, 10 quadrats (each $0.2 \mathrm{~m}^{2} ; 5$ pregrazing and 5 postgrazing quadrats) were randomly collected per group of cows (total of 90 quadrats) during the experiment. The sward 
height was measured with the RPM at the sites of the quadrat and herbage under the plate meter was cut to the ground level. The pre- and postgrazing calibration cuts were collected and then dried in a forced-air oven at $60^{\circ} \mathrm{C}$ for $48 \mathrm{~h}$ to determine herbage DM content. This procedure was conducted in the morning once every 3 to $4 \mathrm{~d}$. These calibration results were used to determine the calibration curve to estimate herbage DM $(\mathrm{kg} / \mathrm{ha})$ in relation to the RPM measurement: $\mathrm{kg}$ of $\mathrm{DM} / \mathrm{ha}$ $=\mathrm{RPM} \times 151.93-112.63\left(\mathrm{R}^{2}=0.803 ; P<0.001\right)$. Using the equation derived from the current experimental data set and grazing areas, the actual herbage mass (DM basis) allocation was $20.9 \mathrm{~kg}$ of DM/cow per day above the ground level. Pre- and postgrazing herbage mass were calculated according to such equation, and group herbage DMI was estimated from herbage disappearance difference between pre- and postgrazing herbage DM mass.

Herbage substitution rate (SR), which is the reduction in herbage DMI kilograms per kilogram of supplement eaten, was calculated daily for supplemented groups using the method described by Penno et al. (2006). Briefly, daily mean of herbage DMI of the unsupplemented group minus the mean herbage DMI of each supplemented group, divided by the DMI from maize silage of the respective day.

Feed. Herbage samples were collected 3 times per week before grazing at $1200 \mathrm{~h}$ to determine its nutritive value. The herbage was cut with shears from the grazing horizon ( $5 \mathrm{~cm}$ above ground level) along a zigzag transect through the pasture strip of each group. Approximately 4 to 5 pluck samples were obtained from each pasture strip. These samples were composited and subsampled for DM content and chemical and botanical composition.

Samples of maize silage (approximately $100 \mathrm{~g}$ fresh) were collected every second day at $1330 \mathrm{~h}$. To determine DM content, maize silage and herbage were immediately subsampled and oven-dried at $60^{\circ} \mathrm{C}$ for $48 \mathrm{~h}$. A second subsample was frozen at $-20^{\circ} \mathrm{C}$ and later freezedried, ground through a 1-mm sieve (ZM200, Retsch, Haan, Germany), and stored for chemical composition analysis. Chemical composition was determined using near-infrared spectroscopy (Feed and Forage Analyzer, Foss Analytical, Hillerød, Denmark). Metabolizable energy of feed was estimated based on the equation $[\mathrm{ME}(\mathrm{MJ} / \mathrm{kg})=$ digestible $\mathrm{OM}$ content $\times 0.016(\mathrm{~g} /$ $\mathrm{kg}$ of DM)] (AFRC, 1993). The starch content of the maize silage was estimated using the Megazyme assay procedure K-TSTA 04/2009 (Megazyme International, Bray, Ireland), and extraction of water-soluble carbohydrates was conducted as described by Pollock and Jones (1979).

Milk. Milk yield $(\mathrm{kg} / \mathrm{d})$ was recorded at each milking (DeLaval Alpro Herd Management System, DeLaval, Tumba, Sweden). Milk subsamples were collected during both morning and afternoon milking on d 13 and 21 using an automatic sampling system. One subsample was analyzed for milk fat, protein, and lactose determination (Livestock Improvement Corporation, Christ-

\section{Treatment}

\section{Control}

2BH

9BH

\section{Measurements}

\begin{tabular}{|l|c|l|l|l|l|}
\hline Standoff & Standoff & Grazing session & Standoff \\
\hline Standoff & Standoff & & & Grazing session & Standoff \\
\hline Standoff
\end{tabular}

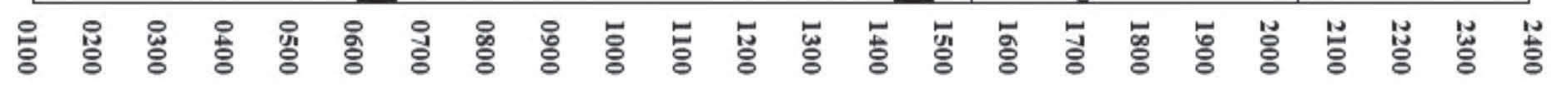
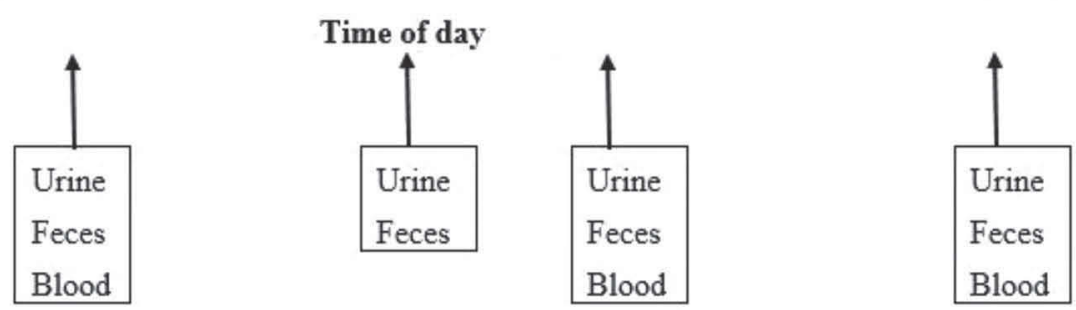

Milking time

Maize silage

Figure 1. Treatments [grazing pasture only (control) or herbage with maize silage at $2(2 \mathrm{BH})$ or 9 (9BH) hours before the herbage meal]; time of milking; and time of urine, feces, and blood sampling of grazing dairy cows. 
church, New Zealand) by MilkoScan (Foss Electric, Hillerød, Denmark). A second subsample was collected for milk urea $\mathrm{N}$ analysis. The MUN concentration was determined in milk subsamples after centrifugation at $4,500 \times g$ for $10 \mathrm{~min}$ at $4^{\circ} \mathrm{C}$ to remove fat, and analysis was conducted using an automated Modular $\mathrm{P}$ analyzer (Roche Hitachi, Basel, Switzerland) as previously described by Talke and Schubert (1965). Milk N content was calculated from Livestock Improvement Corporation determination of protein using a 6.38 factor, in which $\mathrm{N}(\mathrm{g} / \mathrm{kg})=$ protein $(\mathrm{g} / \mathrm{kg}) \times 6.38$.

$\boldsymbol{B} \boldsymbol{W}$ and $\boldsymbol{B} \boldsymbol{C S}$. Body weight was recorded using a weigh scale on d 0,12 , and 21 . An experienced observer determined the BCS of cows, on d 0,12 , and 21, based on a 10-points scale, where 1 is emaciated and 10 is obese (Roche et al., 2009).

Urine and Feces. To estimate the effect of treatments on the $\mathrm{N}$ concentration in feces and urine as the magnitude of difference between treatments, feces and urine spot samples were collected as described by Totty et al. (2013) after milking at 0700, 1200, 1500, and 2100 $\mathrm{h}$, as presented in Figure 1, on d 13 and 21. Briefly, samples were collected during voluntary excretion or manual stimulation. Urine was acidified to a $\mathrm{pH}<4$ to minimize volatilization. All samples were then frozen to $-20^{\circ} \mathrm{C}$ until subsampled. One feces subsample was oven-dried to determine DM content. A second subsample was freeze-dried and then ground to determine $\mathrm{N}$ content. Urine subsamples were analyzed for urine ammonia, creatinine, urea, and total $\mathrm{N}$ concentration. For analysis, feces samples were placed in a fridge to thaw and approximately $50 \mathrm{~g}$ of a representative subsample was freeze-dried for $5 \mathrm{~d}$ at $50 \mathrm{~Pa}$ (Model E. D. 5.3, Cuddon Limited, Blenheim, New Zealand). After freeze-drying, samples were ground through a 1-mm sieve (ZM200, Retsch) and then analyzed for $\mathrm{N}$ concentration by combustion of samples under oxygen supply and high temperature using Varimox CN analyzer (Elementar Analyzensysteme GmbH, Hanau, Germany). The fresh weight of the remainder of the sample was determined, and then these samples were oven-dried at $100^{\circ} \mathrm{C}$ for $48 \mathrm{~h}$ to determine the DM content. Thawed urine samples were inverted and a subsample of approximately $2 \mathrm{~mL}$ was analyzed for urine ammonia, creatinine, urea, and total $\mathrm{N}$ concentration as per kit instructions (Randox Rx Daytona, Randox Laboratories Ltd., Crumlin, UK). Samples from d 21 were analyzed for purine derivatives by HPLC using an Agilent 1100 series (Agilent, Waldbronn, Germany). Urinary $\mathrm{N}(\mathrm{g} / \mathrm{d})$ excretion was estimated using 3 different equations: (1) urinary $\mathrm{N}(\mathrm{g} / \mathrm{d})=[21.9(\mathrm{mg} / \mathrm{kg})$ $\times \mathrm{BW}(\mathrm{kg}) \times(1 /$ urinary creatinine $(\mathrm{mg} / \mathrm{kg})] \times$ urine $\mathrm{N}(\mathrm{g} / \mathrm{kg})$ (Pacheco et al., 2009); (2) urinary N (g/d) $=0.026 \times \mathrm{BW}(\mathrm{kg}) \times \mathrm{MUN}(\mathrm{mg} / \mathrm{dL})($ Kauffman and
St-Pierre, 2001); and (3) urinary N $(\mathrm{g} / \mathrm{d})=1.3 \times \mathrm{BW}$ $(\mathrm{kg}) \times$ plasma urea $\mathrm{N}(\mathrm{g} / \mathrm{L})($ Kohn et al., 2005).

Blood. The blood samples were collected from each cow, via the coccygeal blood vessels, after the morning milking at 0700,1500 , and $2100 \mathrm{~h}$, as presented in Figure 1, on d 13 and 21. Blood samples were collected into $\mathrm{K}_{3}$ EDTA-coated vacuettes for plasma collection and analysis. Blood samples were placed on ice immediately after collection and later centrifuged at $3,000 \times g$ for $10 \mathrm{~min}$ at $4^{\circ} \mathrm{C}$. Plasma was collected into clean tubes then frozen to $-20^{\circ} \mathrm{C}$. Plasma subsamples were used to measure nonesterified fatty acids (NEFA; FA115) and plasma urea N (PUN) concentration using the enzymatic kinetic method (UR 3825).

\section{Statistical Analysis}

The experimental unit in this experiment was the group of cows. The average DMI of the group was analyzed using repeated measures ANOVA with time of maize silage feeding as treatment, day as a repeated measure, and group as replicates. Changes in BW and BCS were analyzed using one way ANOVA with time of maize silage feeding as treatment and group as replicate. Milk solids production and milk compositions were averaged across the 2 sampling days and analyzed using one-way ANOVA with time of maize silage feeding as treatment and group as replicate. Blood, urine, and fecal samples were averaged at each time point across the 2 sampling days and were analyzed using repeated measures ANOVA with time of maize silage feeding as treatment, time of day as a repeated measure, and group as replicate. Results were declared significant at $P<0.05$, and tendency was declared at $P<0.1$.

\section{RESULTS}

The chemical composition of herbage and maize silage are presented in Table 1. Dry matter content was $185 \mathrm{~g} / \mathrm{kg}$ for herbage and $369 \mathrm{~g} / \mathrm{kg}$ for maize silage. The CP was $196 \mathrm{~g} / \mathrm{kg}$ of DM for herbage and $80 \mathrm{~g} / \mathrm{kg}$ of DM for maize silage, and ME concentration was 12.1 and $9.8 \mathrm{MJ} / \mathrm{kg}$ of $\mathrm{DM}$ for herbage and maize silage, respectively.

Herbage DMI was greater for control than supplemented cows, and greater for $9 \mathrm{BH}$ than $2 \mathrm{BH}(P=0.004$; Table 2). Total DMI was greater for supplemented cows than control, and was $0.8 \mathrm{~kg}$ of DM greater for $9 \mathrm{BH}$ than 2BH $(P<0.001$; Table 2$)$. Maize silage DMI did not differ between 2BH and 9BH; however, substitution of herbage by maize silage (kilograms of herbage DM per kilograms of maize silage DM) was lower $(P=$ 0.003 ) for $9 \mathrm{BH}$ than $2 \mathrm{BH}$ (0.19 vs. 0.47 , respectively). 
Table 1. Dry matter (\%), chemical composition (\% of DM), and ME $(\mathrm{MJ} / \mathrm{kg}$ of $\mathrm{DM})$ of herbage and maize silage fed to grazing dairy cows

\begin{tabular}{lcc}
\hline Item & Herbage & Maize silage \\
\hline $\mathrm{DM}$ & 18.5 & 36.9 \\
$\mathrm{ADF}$ & 24.3 & 31.1 \\
$\mathrm{NDF}$ & 43.7 & 54.8 \\
$\mathrm{CP}$ & 19.6 & 8.0 \\
$\mathrm{OM}$ & 90.2 & 96.6 \\
$\mathrm{OMD}^{1}$ & 83.2 & 64.7 \\
DMD $^{2}$ & 78.4 & 60.8 \\
Starch $_{\text {WSC }}^{3}$ & - & 18.2 \\
ME & 16.0 & - \\
\hline
\end{tabular}

${ }^{1} \mathrm{OMD}=\mathrm{OM}$ digestibility.

${ }^{2} \mathrm{DMD}=\mathrm{DM}$ digestibility.

${ }^{3} \mathrm{WSC}=$ water-soluble carbohydrate.

Daily intake of digestible OM, NDF ( $\mathrm{kg}$ of $\mathrm{DM} / \mathrm{d})$, and $\mathrm{ME}(\mathrm{MJ} / \mathrm{d})$ were lower $(P<0.001$; Table 2$)$ for the control than supplemented cows, and lower $(P<$ 0.001; Table 2) for $2 \mathrm{BH}$ than $9 \mathrm{BH}$. In addition, $\mathrm{CP}$ intake $(\mathrm{kg} / \mathrm{d})$ tended $(P=0.07)$ to be greater for $9 \mathrm{BH}$ than control and 2BH. Dietary chemical composition was similar between $2 \mathrm{BH}$ and $9 \mathrm{BH}$, but both were significantly different with the control. Organic matter digestibility $(P=0.002), \mathrm{CP}(P=0.004)$, and $\mathrm{ME}$ $(\mathrm{MJ} / \mathrm{kg} \mathrm{DM} ; P=0.011)$ were greater and fiber content (NDF; $P<0.001$ and ADF; $P=0.04$ ) was lower for control than supplemented cows (Table 2).

We found no difference in milk yield, milk solids production, or the concentration and quantity of fat and protein between treatments. Maize silage supplementation tended to reduced MUN $(P=0.06)$, but we observed no effect of time of supplementation (Table 3). Cows lost BW throughout the trial, with a tendency of greater loss in BW for control than supplemented cows $(P=0.07$; Table 3$)$ and no effect of time of supplementation.

The mean of urine $\mathrm{N}$ concentration, ammonia $\left(\mathrm{NH}_{3}\right)$, and urea concentration were not affected by treatment (Table 4). However, the ratio of purine derivatives (allontoin + uric acid $)$ to creatinine was greater $(P=$ 0.009; Table 4) for supplemented than control cows. The daily mean urea $\mathrm{N}(P=0.05)$ and NEFA $(P<$ 0.001 ) concentration in plasma were greater (Table 4 ) for control than supplemented cows, but did not differ between $2 \mathrm{BH}$ and $9 \mathrm{BH}$. We found a significant treatment $\times$ time of day interaction $(P<0.001$, Table 4$)$ for PUN and NEFA concentration. The concentration of PUN was lower for $2 \mathrm{BH}$ than control and $9 \mathrm{BH}$ at 0700 $\mathrm{h}$, lower for $9 \mathrm{BH}$ than control at $1500 \mathrm{~h}$, and greater for control than $2 \mathrm{BH}$ and $9 \mathrm{BH}$ at $1500 \mathrm{~h}$ (Figure 2a). The concentration of NEFA was lower for $9 \mathrm{BH}$ than $2 \mathrm{BH}$ and control at $0700 \mathrm{~h}$. At $1500 \mathrm{~h}, \mathrm{NEFA}$ concentration was greater for control than $2 \mathrm{BH}$ and $9 \mathrm{BH}$, and greater for $9 \mathrm{BH}$ than $2 \mathrm{BH}$ (Figure $2 \mathrm{~b}$ ).

Estimated $\mathrm{N}$ intake, milk $\mathrm{N}$ output, and urinary $\mathrm{N}$ excretion $(\mathrm{g} / \mathrm{d})$ are presented in Table 5. Estimated $\mathrm{N}$ intake $(\mathrm{g} / \mathrm{d})$ tended $(P=0.07)$ to be greater for $9 \mathrm{BH}$ than control and 2BH. Milk $\mathrm{N}$ output and $\mathrm{N}$ use efficiency (milk $\mathrm{N} / \mathrm{N}$ intake) were not affected by

Table 2. Mean herbage, maize silage, total DM, and nutrient intake; substitution rate (SR); and chemical composition of the diet for cows grazing pasture only (control) or herbage with maize silage at either $9(9 \mathrm{BH})$ or $2 \mathrm{~h}(2 \mathrm{BH})$ before the herbage meal

\begin{tabular}{|c|c|c|c|c|c|}
\hline \multirow[b]{2}{*}{ Item } & \multicolumn{3}{|c|}{ Treatment } & \multirow[b]{2}{*}{ SEM } & \multirow[b]{2}{*}{$P$-value } \\
\hline & Control & $2 \mathrm{BH}$ & $9 \mathrm{BH}$ & & \\
\hline Herbage intake (kg of DM/d) & $11.5^{\mathrm{a}}$ & $10.1^{\mathrm{c}}$ & $10.9^{\mathrm{b}}$ & 0.18 & 0.004 \\
\hline Maize silage intake (kg of DM/d) & - & 3.0 & 3.0 & 0.01 & 0.37 \\
\hline Total intake $(\mathrm{kg}$ of DM/d) & $11.5^{\mathrm{c}}$ & $13.1^{\mathrm{b}}$ & $13.9^{\mathrm{a}}$ & 0.17 & $<0.001$ \\
\hline SR & - & $0.47^{\mathrm{a}}$ & $0.19^{\mathrm{b}}$ & 0.030 & 0.003 \\
\hline \multicolumn{6}{|l|}{ Intake } \\
\hline $\mathrm{DOM}^{1}(\mathrm{~kg}$ of $\mathrm{DM} / \mathrm{d})$ & $9.5^{\mathrm{c}}$ & $10.3^{\mathrm{b}}$ & $11.0^{\mathrm{a}}$ & 0.14 & $<0.001$ \\
\hline $\mathrm{CP}(\mathrm{kg}$ of $\mathrm{DM} / \mathrm{d})$ & $2.3^{\mathrm{y}}$ & $2.2^{\mathrm{y}}$ & $2.4^{\mathrm{x}}$ & 0.04 & 0.07 \\
\hline $\mathrm{ADF}(\mathrm{kg}$ of DM/d) & $2.8^{\mathrm{b}}$ & $3.4^{\mathrm{a}}$ & $3.6^{\mathrm{a}}$ & 0.07 & $<0.001$ \\
\hline $\mathrm{NDF}(\mathrm{kg}$ of $\mathrm{DM} / \mathrm{d})$ & $5.0^{\mathrm{c}}$ & $6.0^{\mathrm{b}}$ & $6.4^{\mathrm{a}}$ & 0.09 & $<0.001$ \\
\hline $\mathrm{ME}(\mathrm{MJ} / \mathrm{d})$ & $139^{\mathrm{c}}$ & $151^{\mathrm{b}}$ & $161^{\mathrm{a}}$ & 2.1 & $<0.001$ \\
\hline \multicolumn{6}{|l|}{ Diet composition (\% of DM) } \\
\hline $\mathrm{OMD}^{2}$ & $83.2^{\mathrm{a}}$ & $79.0^{\mathrm{b}}$ & $79.2^{\mathrm{b}}$ & 0.50 & 0.002 \\
\hline $\mathrm{CP}$ & $19.6^{\mathrm{a}}$ & $17.0^{\mathrm{b}}$ & $17.1^{\mathrm{b}}$ & 0.37 & 0.004 \\
\hline $\mathrm{ADF}$ & $24.3^{\mathrm{b}}$ & $26.0^{\mathrm{a}}$ & $26.0^{\mathrm{a}}$ & 0.35 & 0.038 \\
\hline NDF & $43.7^{\mathrm{b}}$ & $46.2^{\mathrm{a}}$ & $46.1^{\mathrm{a}}$ & 0.22 & $<0.001$ \\
\hline $\mathrm{ME}$ & $12.1^{\mathrm{a}}$ & $11.6^{\mathrm{b}}$ & $11.6^{\mathrm{b}}$ & 0.09 & 0.011 \\
\hline
\end{tabular}


Table 3. Milk yield; milk solids; concentration of fat, protein, and urea $\mathrm{N}$ in milk; fat and protein production; and change in BW and BCS for cows grazing pasture only (control) or herbage with maize silage at either 9 $(9 \mathrm{BH})$ or $2 \mathrm{~h}(2 \mathrm{BH})$ before the herbage meal

\begin{tabular}{lccccc}
\hline & \multicolumn{3}{c}{ Treatment } & & \\
\cline { 2 - 4 } Item & Control & $2 \mathrm{BH}$ & $9 \mathrm{BH}$ & \multirow{2}{*}{ SEM } & $P$-value \\
\hline Milk yield (kg/d) & 11.6 & 12.8 & 13.0 & 0.69 & 0.36 \\
Milk solids (kg/d) & 1.12 & 1.20 & 1.26 & 0.045 & 0.22 \\
Fat (\%) & 5.78 & 5.51 & 5.75 & 0.157 & 0.47 \\
Protein (\%) & 4.04 & 3.98 & 4.04 & 0.096 & 0.88 \\
Fat (kg/d) & 0.66 & 0.69 & 0.74 & 0.026 & 0.18 \\
Protein (kg/d) & 0.47 & 0.51 & 0.52 & 0.023 & 0.32 \\
MUN (mmol/L) & $6.5^{\mathrm{x}}$ & $5.2^{\mathrm{y}}$ & $5.6^{\mathrm{y}}$ & 0.33 & 0.06 \\
Change in BW (kg/d) & $-0.95^{\mathrm{x}}$ & $-0.44^{\mathrm{y}}$ & $-0.58^{\mathrm{y}}$ & 0.127 & 0.07 \\
Change in BCS & -0.46 & -0.30 & -0.38 & 0.107 & 0.58 \\
\hline
\end{tabular}

${ }^{x, y}$ Means within a row with different superscripts differ $(P<0.1)$.

treatments. When urinary $\mathrm{N}$ excretion was calculated using the creatinine-based equation, estimated urinary $\mathrm{N}$ excretion was not affected by treatment. However, urinary $\mathrm{N}$ excretion tended to be greater for control than supplemented cows when urinary $\mathrm{N}$ excretion was calculated using equations based MUN $(P=0.09)$ or PUN $(P=0.08)$, respectively.

\section{DISCUSSION}

\section{Intake and Herbage Substitution}

Estimated herbage DMI was greater for the control than supplemented cows. This suggests that maize silage supplementation caused a reduction in herbage DMI, as observed in previous studies (Morrison and Patterson, 2007; Burke et al., 2008; Pérez-Prieto et al., 2011). Maize silage supplementation resulted in an average SR of 0.33 , which is relatively close to the 0.44 reported by Burke et al. (2008) for grazing dairy cows allocated a similar herbage allowance and supplemented with $3.2 \mathrm{~kg}$ of DM of maize silage/cow per day. Pérez-Prieto et al. (2011) reported an SR of 0.51 when late-lactating dairy cows were supplemented with 6.8 $\mathrm{kg}$ of DM of maize silage and allocated to $18 \mathrm{~kg}$ of DM of herbage. The difference in SR between studies could be explained by the greater amount of supplement in the study of Pérez-Prieto et al. (2011). This premise is supported by the study of Stockdale (2000), who reported an increase in SR with the increase in supplement intake.

Estimated herbage DMI was greater for $9 \mathrm{BH}$ than $2 \mathrm{BH}$. This reflects the greater SR for $2 \mathrm{BH}$ than $9 \mathrm{BH}$. Similarly, Al-Marashdeh et al. (2015a) and Al-Marashdeh et al. (2015b) reported, in an indoor study, a greater herbage DMI by supplementing cows with maize silage at 9 rather than $1 \mathrm{~h}$ before the herbage meal. Two possible reasons exist for the difference in $\mathrm{SR}$ between $2 \mathrm{BH}$ and 9BH. First, rumen fill constraints could have been greater for $2 \mathrm{BH}$ than $9 \mathrm{BH}$ at the time the grazing ses-

Table 4. Fecal $\mathrm{N}$ and urine $\mathrm{N}(\%)$, ammonia $\left(\mathrm{NH}_{3}\right)$, urea $\mathrm{N}$, and purine derivatives (allontoin + uric acid)-to-creatinine (PD:C) ratio, and plasma concentration of urea $\mathrm{N}$ and nonesterified fatty acids (NEFA) for cows grazing pasture only (control) or herbage with maize silage either at $9(9 \mathrm{BH})$ or $2 \mathrm{~h}(2 \mathrm{BH})$ before the herbage meal

\begin{tabular}{|c|c|c|c|c|c|c|c|}
\hline Item & \multicolumn{3}{|c|}{ Treatment } & SEM & \multicolumn{3}{|c|}{$P$-value } \\
\hline \multicolumn{8}{|l|}{ Feces } \\
\hline \multicolumn{8}{|l|}{ Urine } \\
\hline $\mathrm{N}(\%)$ & 0.35 & 0.36 & 0.40 & 0.037 & 0.61 & 0.003 & 0.10 \\
\hline $\mathrm{NH}_{3}(\mathrm{mmol} / \mathrm{L})$ & 1.43 & 1.94 & 1.60 & 0.261 & 0.43 & 0.020 & 0.25 \\
\hline \multicolumn{8}{|l|}{ Plasma } \\
\hline Urea $\mathrm{N}(\mathrm{mmol} / \mathrm{L})$ & $11.7^{\mathrm{a}}$ & $9.3^{\mathrm{b}}$ & $9.7^{\mathrm{b}}$ & 0.57 & 0.05 & $<0.001$ & $<0.001$ \\
\hline NEFA $(\mathrm{mmol} / \mathrm{L})$ & $0.30^{\mathrm{a}}$ & $0.15^{\mathrm{b}}$ & $0.13^{\mathrm{b}}$ & 0.012 & $<0.001$ & $<0.001$ & $<0.001$ \\
\hline
\end{tabular}

${ }^{\mathrm{a}, \mathrm{b}}$ Means within a row with different superscripts differ $(P<0.05)$.

${ }^{1}$ Treatment effect.

${ }^{2}$ Time of sampling effect. 

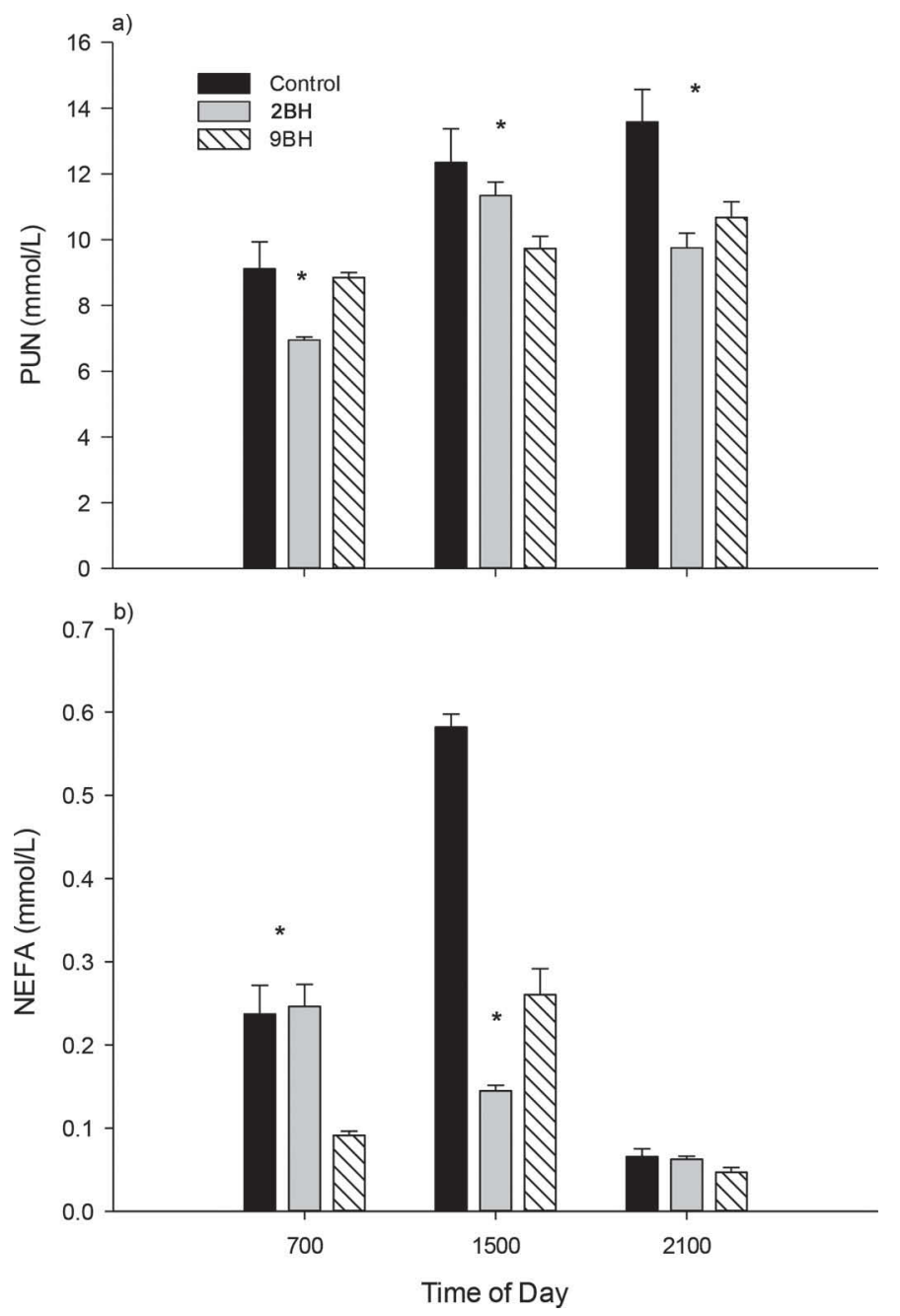

Figure 2. Diurnal changes in (a) plasma urea N (PUN) and (b) nonesterified fatty acids (NEFA) for lactating dairy cows grazing pasture only (control) or herbage with maize silage at $2(2 \mathrm{BH})$ or $9 \mathrm{~h}$ $(9 \mathrm{BH})$ before the herbage meal. Bars indicate SEM. *Asterisks indicate significant differences $(\mathrm{P}<0.05)$ between means at a particular sampling time. sion started. Increments of the rumen fill were reported to accelerate satiation, reduce grazing time, bite mass, and intake rate, and thereby reduce DMI (Chilibroste et al., 2007; Gregorini et al., 2007, 2009). Second, a longer fasting period before the time of herbage meal for cows in $9 \mathrm{BH}$ as compared with cows in $2 \mathrm{BH}$; in other words, the level of hunger, as suggested by Gregorini et al. (2009) and Soca et al., (2014). At the time of the herbage meal, $9 \mathrm{~h}$ had elapsed from the last meal for $9 \mathrm{BH}$ compared with only $2 \mathrm{~h}$ for $2 \mathrm{BH}$. Therefore, $9 \mathrm{BH}$ cows could have been hungrier than $2 \mathrm{BH}$ cows and, thereby, be more motivated to graze (Gregorini et al., 2009; Forbes and Gregorini, 2015). Gregorini et al. (2009) and Chilibroste et al. (2007) reported that herbage intake rate increases as time since the last meal increases. This premise is supported by the result of NEFA concentrations at the time the grazing session started (at $1500 \mathrm{~h}$ ). Control had the greatest concentration of NEFA and herbage intake, whereas the lowest concentration of NEFA was associated with lowest herbage intake for 2BH. Gregorini et al. (2009) and Van Itallie and Hashim (1960) reported that NEFA is an index of readiness to consume more food. During the first grazing session (0800-1200 h) in the study of Gregorini et al. (2009), greater NEFA concentration was associated with greater ghrelin concentration and also greater herbage intake for dairy cows grazing for $8 \mathrm{~h}$ than those grazed for 2 periods of $4 \mathrm{~h}$ or unrestricted. In addition, Soca et al. (2014) reported a greater grazing efficiency and longer initial grazing bouts for lactating dairy cows when restricted time at pasture increased from 0 to 4 to $8.5 \mathrm{~h}$. Although, ghrelin was not measured in the current study, our results support the hypothesis that feeding maize silage at 2 rather than $9 \mathrm{~h}$ before a short and intensive grazing session reduces the motivation to graze and herbage DMI.

Quantifying daily herbage DMI by cattle is challenging, and there are several techniques and methods to do it. One of these techniques is based on the estimation

Table 5. Estimated N intake, milk output, and urinary N excretion for cows grazing pasture only (control) or herbage with maize silage either at $9(9 \mathrm{BH})$ or $2 \mathrm{~h}(2 \mathrm{BH})$ before the herbage meal

\begin{tabular}{lcccrc}
\hline & \multicolumn{3}{c}{ Treatment } & & \\
\cline { 2 - 4 } Item & Control & $2 \mathrm{BH}$ & \multirow{2}{*}{$9 \mathrm{BH}$} & SEM & $P$-value \\
\hline Estimated N intake (g/d) & $360^{\mathrm{y}}$ & $354^{\mathrm{y}}$ & $381^{\mathrm{x}}$ & 7.0 & 0.07 \\
Milk & & & & & \\
$\quad$ N output (g/d) & 73.0 & 80.0 & 82.0 & 3.70 & 0.28 \\
Milk N:total N intake (\%) & 20.3 & 22.5 & 22.0 & 1.30 & 0.50 \\
Urinary N excretion (g/d) & 165 & 147 & 159 & 13.3 & 0.45 \\
$\quad$ Estimated by creatinine & $210^{\mathrm{x}}$ & $172^{\mathrm{y}}$ & $183^{\mathrm{y}}$ & 10.5 & 0.09 \\
Estimated by MUN & $188^{\mathrm{x}}$ & $155^{\mathrm{y}}$ & $161^{\mathrm{y}}$ & 8.7 & 0.08 \\
Estimated by plasma urea N & & & & & \\
\hline
\end{tabular}

${ }^{\mathrm{x}, \mathrm{y}}$ Means within a row with different superscripts differ $(P<0.1)$. 
of herbage mass disappearance (difference between preand postgrazing herbage DM mass) during the grazing period (Moore, 1996). Results from this technique are estimates of herbage DMI with variable associated error depending on the sward type and condition (Burns et al., 1994; Moore, 1996). In the current study, we used the herbage DM disappearance technique to estimate herbage DMI. One of the limitations of this technique is the accuracy of the plate meter calibration between RPM reading and herbage DM mass. In the current study, calibrations between sward surface height and herbage DM mass were derived during the experiment using herbage grazed by cows to minimize error in estimation. We observed a close relationship between sward surface height and herbage DM mass $\left(\mathrm{R}^{2}=0.803 ; P\right.$ $<0.001)$. Calibrations used to estimate herbage DM disappearance were based on both pre- and postquadrat cuts with a range of compressed sward surface height from 3.0 to $16.6 \mathrm{~cm}$. This approach minimized some of the known estimation errors of herbage DM disappearance from using calibration curves derived from pregrazing herbage DM mass alone. Despite its limitations, this technique has been reported to provide an acceptable estimate of herbage DM disappearance and then intake at group level (Moore, 1996; Macoon et al., 2003). It has also been successfully used under New Zealand grazing conditions (Penno et al., 2006; Gregorini et al., 2009; Totty et al., 2013) to infer the herbage intake dynamic of dairy cows grazing relatively homogeneous swards of ryegrass.

\section{Milk Solids Production, BW, and BCS}

Stage of lactation in cattle modulates nutrient partitioning. During late lactation, lactating cattle partition more nutrients toward lean and lipid tissues than milk production (Stockdale, 2007). Although milk solids production was not influenced by supplementation in the current study, the loss of BW tended to be less in supplemented cows. This implies that maize silage supplementation attenuates the effect of restriction of time at pasture. Although, milk production was not affected by maize silage supplementation, Moran et al. (1986) reported an increase in BW gain from 0.4 to 0.5 to $0.7 \mathrm{~kg} / \mathrm{d}$ when cows were supplemented with 0,3 , and $8 \mathrm{~kg}$ of DM of maize silage per day, respectively. This may be explained by the greater ME intake along with the greater ME-to-CP ratio in both Moran et al. (1986) and the current study. Moran et al. (1986) suggested that herbage and maize silage as a complimentary feeds due to the effect of starch on improving the utilization of $\mathrm{N}$ supplied by herbage. In addition, it was reported that the proportion of ME intake used for BW gain may vary depending on rumen fermentation end products associated with different feedstuff (Molina et al., 1991; Mandok et al., 2012). Starch content of maize silage may result in a greater glucogenic supply, which in late lactation can stimulate lipogenesis and or reduce lipolysis, having a direct effect on BW gain (Stockdale, 2007).

In the current study, we found no evidence that time of supplementation influenced milk production or composition. This implies that the extra $10 \mathrm{MJ} / \mathrm{d}$ of $\mathrm{ME}$ intake for $9 \mathrm{BH}$ compared with $2 \mathrm{BH}$, as a result of 0.8 $\mathrm{kg}$ increase in herbage DMI, may have not been enough to produce a significant difference in milk production between $9 \mathrm{BH}$ and $2 \mathrm{BH}$.

\section{N Metabolism and Partitioning}

Maize silage was proposed to dilute $\mathrm{N}$ intake, which is often supplied by herbage, reduce $\mathrm{N}$ intake, and hence reduce urinary N excretion (Valk, 1994; Gregorini et al., 2010a). However, in our study, feeding maize silage only resulted in a small difference in $\mathrm{N}$ intake between treatments $(360,354$, and $381 \mathrm{~g}$ of $\mathrm{N} / \mathrm{cow}$ per day for control, $2 \mathrm{BH}$, and 9BH, respectively). Although maize silage has a relatively low $\mathrm{N}$ content $(12.8 \mathrm{~g} / \mathrm{kg}$ of $\mathrm{DM})$, DMI was increased resulting in similar $\mathrm{N}$ intake across treatments.

Feeding maize silage reduced MUN and PUN concentration. These results may reflect better utilization of ruminal $\mathrm{NH}_{3}-\mathrm{N}$ and, hence, greater microbial protein yield in supplemented cows. No direct measurement was made of microbial protein production; however, purine derivatives may be used as indicators of microbial production (Shingfield, 2000). Urinary creatinine is directly related to the body mass and excreted at a constant rate (Hayden et al., 1992). The ratio of purine derivatives to creatinine was greater for supplemented cows than control. This suggests a greater yield of microbial protein for supplemented cows than control, and may explain the tendency of greater urinary $\mathrm{N}$ excretion for control than supplemented cows when urinary $\mathrm{N}$ excretion was calculated using MUN or PUN. Similarly, Al-Marashdeh et al. (2015a) reported lower urinary N excretion for cows supplemented with $3 \mathrm{~kg}$ of DM of maize silage than those fed herbage only. The reason for this increase in the indicator of microbial protein production and the subsequent reduction in urinary $\mathrm{N}$ excretion may be attributed to the relative increase in the ME-to-N ratio for supplemented cows than control (0.43 vs. $0.38 \mathrm{MJ}$ of $\mathrm{ME} / \mathrm{g}$ of $\mathrm{N}$, respectively). Cabrita et al. (2006) reported that imbalances between $\mathrm{N}$ and energy supply to rumen microbes minimizes the utilization of RDP and its conversion to microbial protein. This suggests better utilization of $\mathrm{N}$ intake (greater amount of protein pass the rumen) may be achieved 
with a greater ME-to-N ratio (Castillo et al., 2000; Pacheco and Waghorn, 2008).

The absolute value of estimate urinary $\mathrm{N}$ excretion was different according to the parameter used to calculate the estimate, but the rankings of urinary $\mathrm{N}$ excretion calculated by different methods were similar. Similar rankings of estimated urinary $\mathrm{N}$ excretion were observed by the study of Al-Marashdeh et al. (2015a), when urinary $\mathrm{N}$ excretion was greater for control than supplemented cows and greater for cows supplemented with $3 \mathrm{~kg}$ of maize silage in the morning than those supplemented with the same amount but in the afternoon.

\section{CONCLUSIONS}

In situations where available grazing time is restricted, the time of maize silage supplementation, 9 rather than $2 \mathrm{~h}$ before herbage allocation, reduces the substitution rate and increases herbage DMI by dairy cows. Increments of herbage DMI at the same resourcefeed allocations are crucial in pastoral dairy systems, as profitability of dairy farms is intimately related to herbage intake and utilization. Despite the greater levels of herbage, and thereby $\mathrm{N}$ intake, urinary $\mathrm{N}$ excretion was not increased by feeding maize silage 9 rather than $2 \mathrm{~h}$ before an intensive meal of temperate grass of herbage.

\section{REFERENCES}

AFRC. 1993. Energy and protein requirements of ruminants: An advisory manual prepared by the AFRC Technical Committee on Responses to Nutrients. Commonwealth Agricultural Bureaux, Farnham Royal, UK.

Al-Marashdeh, O., S. L. Greenwood, S. Hodge, and G. R. Edwards. 2015a. The effects of feeding maize silage at different times prior to a herbage meal on dry matter intake, milk solids production and nitrogen excretion in late-lactation dairy cows. Proc. N.Z. Soc. Anim. Prod. 75:140-144.

Al-Marashdeh, O., P. Gregorini, S. L. Greenwood, and G. Edwards. 2015b. The effect of feeding maize silage $1 \mathrm{~h}$ or $9 \mathrm{~h}$ before the herbage meal on dry matter intake, milk production, nitrogen partitioning and rumen function of lactating dairy cows. Anim. Prod. Sci. http://dx.doi.org/10.1071/AN14790.

Burke, F., M. A. O'Donovan, J. J. Murphy, F. P. O'Mara, and F. J. Mulligan. 2008. Effect of pasture allowance and supplementation with maize silage and concentrates differing in crude protein concentration on milk production and nitrogen excretion by dairy cows. Livest. Sci. 114:325-335.

Burns, J. C., K. R. Pond, and D. S. Fisher. 1994. Measurement of forage intake. Page 494 in Forage Quality, Evaluation, and Utilization. G. C. Fahey, M. Collins, D. R. Mertens, and L. E. Moser, ed. American Society of Agronomy, Crop Science Society of America, Soil Science Society of America, Madison, WI.

Cabrita, A., R. J. Dewhurst, J. Abreu, and A. Fonseca. 2006. Evaluation of the effects of synchronising the availability of $\mathrm{N}$ and energy on rumen function and production responses of dairy cows- $\mathrm{A}$ review. Anim. Res. 55:1-24.

Castillo, A. R., E. Kebreab, D. E. Beever, J. H. Barbi, J. D. Sutton, H. C. Kirby, and J. France. 2001. The effect of energy supplementa- tion on nitrogen utilization in lactating dairy cows fed grass silage diets. J. Anim. Sci. 79:240-246.

Castillo, A. R., E. Kebreab, D. E. Beever, and J. France. 2000. A review of efficiency of nitrogen utilisation in lactating dairy cows and its relationship with environmental pollution. J. Anim. Feed Sci. 9:1-32.

Chilibroste, P., P. Soca, D. A. Mattiauda, O. Bentancur, and P. H. Robinson. 2007. Short term fasting as a tool to design effective grazing strategies for lactating dairy cattle: A review. Aust. J. Exp. Agric. 47:1075-1084.

Clark, C. E., K. McLeod, C. Glassey, P. Gregorini, D. Costall, K. Betteridge, and J. Jago. 2010. Capturing urine while maintaining pasture intake, milk production, and animal welfare of dairy cows in early and late lactation. J. Dairy Sci. 93:2280-2286.

De Klein, C. A. M., R. M. Monaghan, S. F. Ledgard, and M. Shepherd. 2010. A system's perspective on the effectiveness of measures to mitigate the environmental impacts of nitrogen losses from pastoral dairy farming. Pages 14-28 in Proc. Proceedings of the 4th Australasian Dairy Science Symposium, Lincoln University, Christchurch, New Zealand. Australasian Dairy Science Symposium, Christchurch, New Zealand.

Forbes, J. M., and P. Gregorini. 2015. The catastrophe of meal eating. Anim. Prod. Sci. 55:350-359.

Gekara, O. J., E. Prigge, W. Bryan, E. Nestor, and G. Seidel. 2005. Influence of sward height, daily timing of concentrate supplementation, and restricted time for grazing on forage utilization by lactating beef cows. J. Anim. Sci. 83:1435-1444.

Gregorini, P. 2012. Diurnal grazing pattern: its physiological basis and strategic management. Anim. Prod. Sci. 52:416-430.

Gregorini, P., P. C. Beukes, R. H. Bryant, and A. J. Romera. 2010a. A brief overview and simulation of the effects of some feeding strategies on nitrogen excretion and enteric methane emission from grazing dairy cows. Pages $29-43$ in Proc. Proceedings of the 4th Australasian Dairy Science Symposium, Lincoln University, Christchurch, New Zealand. Australasian Dairy Science Symposium, Christchurch, New Zealand.

Gregorini, P., C. E. F. Clark, J. G. Jago, C. B. Glassey, K. L. M. McLeod, and A. J. Romera. 2009. Restricting time at pasture: Effects on dairy cow herbage intake, foraging behavior, hungerrelated hormones, and metabolite concentration during the first grazing session. J. Dairy Sci. 92:4572-4580.

Gregorini, P., S. A. Gunter, C. A. Masino, and P. A. Beck. 2007. Effects of ruminal fill on short-term herbage intake rate and grazing dynamics of beef heifers. Grass Forage Sci. 62:346-354.

Gregorini, P., K. J. Soder, and G. Waghorn. 2010b. Effects of timing of corn silage supplementation on digestion, fermentation pattern, and nutrient flow during continuous culture fermentation of a short and intensive orchardgrass meal. J. Dairy Sci. 93:3722-3729.

Hayden, J. M., W. Bergen, and R. Merkel. 1992. Skeletal muscle protein metabolism and serum growth hormone, insulin, and cortisol concentrations in growing steers implanted with estradiol-17 beta, trenbolone acetate, or estradiol-17 beta plus trenbolone acetate. J. Anim. Sci. 70:2109-2119.

Hess, B. W., P. A. Ludden, E. J. Scholljegerdes, and V. Nayigihugu. 2002. Effects of time of daily cracked corn supplementation on site and extent of digestion in cattle grazing summer cool-season pasture. Proc. West. Sect. Am. Soc. Anim. Sci. 53:651-654.

Kauffman, A. J., and N. St-Pierre. 2001. The relationship of milk urea nitrogen to urine nitrogen excretion in Holstein and Jersey cows. J. Dairy Sci. 84:2284-2294.

Kellaway, R., R. Tassell, E. Havilah, N. Sriskandarajah, and A. Andrews. 1993. Nutrient balance in the diet of grazing dairy cows. Crop Pasture Sci. 44:423-430.

Kohn, R. A., M. Dinneen, and E. Russek-Cohen. 2005. Using blood urea nitrogen to predict nitrogen excretion and efficiency of nitrogen utilization in cattle, sheep, goats, horses, pigs, and rats. J. Anim. Sci. 83:879-889.

Macoon, B., L. Sollenberger, J. Moore, C. Staples, J. Fike, and K. Portier. 2003. Comparison of three techniques for estimating the forage intake of lactating dairy cows on pasture. J. Anim. Sci. $81: 2357-2366$. 
Mandok, K. S., J. K. Kay, S. L. Greenwood, G. R. Edwards, M. Crookenden, and J. R. Roche. 2012. The efficiency with which metabolisable energy is used for live weight gain differs between feed types. Pages 338-342 in Proceedings of the 5th Australasian Dairy Science Symposium, vol. 5. Australasian Dairy Science Symposium, Melbourne, Australia.

Mitani, T., M. Takahashi, K. Ueda, H. Nakatsuji, and S. Kondo. 2005. Effects of pre-feeding of a corn silage-based supplement on the feed intake, milk production and nitrogen utilization of grazing dairy cows. Anim. Sci. J. 76:453-460.

Molina, R. D., G. Meschia, F. C. Battaglia, and W. Hay. 1991. Gestational maturation of placental glucose transfer capacity in sheep. Am. J. Physiol. 261:R697-704.

Moore, J. E. 1996. Practical approaches to estimating pasture intake. Page 193 in Proceedings, Nutrient Cycling in Forage Systems. R. E. Joost and C. A. Roberts, ed. Center for Pasture Management, Univ. of Missouri, Columbia, MO.

Moran, J., C. Stockdale, and T. Trigg. 1986. Maize silage as a supplement for grazing dairy cows. Proc. Aust. Soc. Anim. Prod. 16:283286.

Morrison, S. J., and D. C. Patterson. 2007. The effects of offering a range of forage and concentrate supplements on milk production and dry matter intake of grazing dairy cows. Grass Forage Sci. 62:332-345.

Oudshoorn, F. W., T. Kristensen, and E. S. Nadimi. 2008. Dairy cow defecation and urination frequency and spatial distribution in relation to time-limited grazing. Livest. Sci. 113:62-73.

Pacheco, D., K. Lowe, J. L. Burke, and G. P. Cosgrove. 2009. Urinary nitrogen excretion from cows at different stage of lactation grazing different ryegrass cultivars during spring or autumn. Proc. N.Z. Soc. Anim. Prod. 69:196-200.

Pacheco, D., and G. C. Waghorn. 2008. Dietary nitrogen-definitions, digestion, excretion and consequences of excess for grazing ruminants. Proc. N. Z. Grassl. Assoc. 70:107-116.

Penno, J. W., K. A. MacDonald, C. W. Holmes, S. R. Davis, G. F. Wilson, I. M. Brookes, and E. R. Thom. 2006. Responses to supplementation by dairy cows given low pasture allowances in different seasons 1. Pasture intake and substitution. Anim. Sci. 82:661-670.

Pérez-Prieto, L. A., J. Peyraud, and R. Delagarde. 2011. Substitution rate and milk yield response to corn silage supplementation of late-lactation dairy cows grazing low-mass pastures at 2 daily allowances in autumn. J. Dairy Sci. 94:3592-3604.
Pérez-Ramírez, E., R. Delagarde, and L. Delaby. 2008. Herbage intake and behavioural adaptation of grazing dairy cows by restricting time at pasture under two feeding regimes. Animal 2:1384-1392.

Pollock, C. J., and T. Jones. 1979. Seasonal patterns of fructan metabolism in forage grasses. New Phytol. 83:9-15.

Roche, J. R., N. C. Friggens, J. K. Kay, M. W. Fisher, K. J. Stafford, and D. P. Berry. 2009. Invited review: Body condition score and its association with dairy cow productivity, health and welfare. J. Dairy Sci. 92:5769-5801.

Sheahan, A. J., S. J. Gibbs, and J. R. Roche. 2013. Timing of supplementation alters grazing behavior and milk production response in dairy cows. J. Dairy Sci. 96:477-483.

Shingfield, K. J. 2000. Estimation of microbial protein supply in ruminant animals based on renal and mammary purine metabolite excretion. A review. J. Anim. Feed Sci. 9:169-212.

Soca, P., H. González, H. Manterola, M. Bruni, D. Mattiauda, P. Chilibroste, and P. Gregorini. 2014. Effect of restricting time at pasture and concentrate supplementation on herbage intake, grazing behaviour and performance of lactating dairy cows. Livest. Sci. 170:35-42.

Stockdale, C. R. 2000. Levels of pasture substitution when concentrates are fed to grazing dairy cows in northern Victoria. Aust. J. Exp. Agric. 40:913-921.

Stockdale, C. R. 2007. Effects of body condition and diet in late gestation on the subsequent health and performance of dairy cows. Anim. Prod. Sci. 47:495-501.

Talke, H., and G. E. Schubert. 1965. Enzymatic determination in the blood and serum in the Warburg Optical test. Klin. Wochenschr. 43:174-175.

Totty, V. K., S. Greenwood, R. Bryant, and G. Edwards. 2013. Nitrogen partitioning and milk production of dairy cows grazing simple and diverse pastures. J. Dairy Sci. 96:141-149.

Valentine, I., and P. D. Kemp. 2007. Pasture and supplement resources. Pages 3-11 in Pasture and Supplements for Grazing Animals. P. V. Rattray, I. M. Brookes, and A. M. Nicol, ed. New Zealand Society of Animal Production Occasional Publication Number 14, Hamilton, New Zealand.

Valk, H. 1994. Effects of partial replacement of herbage by maize silage on $\mathrm{N}$ utilization and milk production of dairy cows. Livest. Prod. Sci. 40:241-250.

Van Itallie, T. B., and S. A. Hashim. 1960. Biochemical concomitants of hunger and satiety in man. Am. J. Clin. Nutr. 8:587-593. 